\title{
THE BALANCE BETWEEN CUT AND INCREMENT IN SWEDEN, FINDLAND AND NORWAY
}

\section{By Paul Bellander*}

$\Lambda \mathrm{T}$ the present time, when the attention of Canadian foresters is centreed

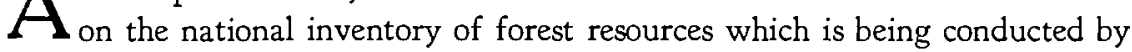
Federal and Provincial authorities, it is of interest to study the results of similar inventories which have been completed in the Scandinavian countries. Sweden, Finland, and Norway have each recently finished a general cruise of their forest areas and the findings of these three important undertakings have been summarized and compared by Bellander, a prominent Swedish forester and lumberman.

As stated in the report of the Canadian conference on the subject, a national inventory is required as the basis for the establishment of a balance between forest growth and depletion. Bellander's article, as its name indicates, analyzes the results of the Scandinavian surveys, to see how nearly such a balance exists.

With minor corrections for later, more accurate results for Sweden, issued by the authorities of that country subsequent to the appearance of Bellander's article, the significant figures for the three countries are given in the two following tables.

\section{TABLE 1.}

$\begin{array}{lccc}\text { Species } & \begin{array}{c}\text { Total annual } \\ \text { increment }\end{array} & \begin{array}{c}\text { Proportion } \\ \text { not exploitable } \\ 11 \%\end{array} & \begin{array}{r}\text { Accessible } \\ \text { increment }\end{array} \\ \text { Pine } & 18.2 \text { million cu.m. } & 16.2 \text { million } \\ \text { Spruce } & 19.8 \text { million cu.m. } & 9 \% & 18.0 \text { million } \\ \text { Broadleaves } & 9.7 \text { million cu.m. } & 25 \% & 7.3 \text { million }\end{array}$

Total 47.7 million cu.m.

41.5 million

Table 2. Summary of Areas and Volumes

\begin{tabular}{|c|c|c|c|c|c|}
\hline \multirow[b]{2}{*}{ Country } & \multirow[t]{2}{*}{$\begin{array}{c}\text { Total } \\
\text { Productive } \\
\text { Area }\end{array}$} & \multicolumn{4}{|c|}{$\begin{array}{l}\text { Total Cubic Volume } \\
\text { (excluding bark) } \\
\text { Millions of cubic feet }\end{array}$} \\
\hline & & Pine & Spruce & Broadleaf & Total \\
\hline Sweden & 89,500 & 17,420 & 18,100 & 7,540 & 43,060 \\
\hline Finland & 97,800 & 23,610 & 14,610 & 11,000 & 49,220 \\
\hline Norway & 29,100 & 3,190 & 6,230 & 2,640 & 12,060 \\
\hline Total & 216,400 & 44,220 & 38,940 & 21,180 & 104,340 \\
\hline
\end{tabular}

*Based on translation by S. R. Schenstrom, B.C. Forest Service, of article in "Skogen," Vol. 16, No. 20, Pp. 535-541. Oct. 15, 1929. 
The results of the surveys are comparable, on the whole, although in Finland the standard for productive forest land is stated to be lower than in the other countries, types of soil being included which in Sweden and Norway would be considered too poor for forestry purposes.

For each country, Bellander gives figures of productive forest area, total cubic volume, annual wood consumption, and forest increment. The latter is given first as total increment, from which are deducted quantities due to self-thinning, insect damage, and inaccessibility. Annual losses from decay are apparently disregarded. The net growth calculated in this way is referred to as the accessible increment. For Sweden, as an example, the increment is stated in table 2 :

By comparing the average annual consumption and the increment for the period 1925-27, it is found that in Sweden there exists a surplus of $1 \%$ of the yearly cut, and in Finland and Norway deficits of $16 \%$ and $10 \%$ respectively. These over-cuts may be regarded as a consequence of the uneven distribution of the age classes rather than actual depletion of the forest capital. Both countries have a surplus of overmature timber and a shortage of middle age classes. As the virgin stands are reduced the deficit will continue until the present young forests grow to merchantable sizes and the annual cut is adjusted to conform to a complete range of age classes.

The least reliable figures are considered to be those for wood consump. tion. Norway has carried out a survey of this subject and is able to furnish accurate data. In the other countries the totals are based on returns from government forests, logging companies and private forest owners who keep records. The most unsatisfactory values are considered to be those for wood cut for domestic purposes.

In each country both the total cubic volume and the increment have been found to be higher than was expected, the extra quantities being due to greater numbers of small trees and larger areas of inaccessible land, poten. tially valuable, than had been estimated.

Bellander presents, finally, an estimate of the growth-consumption balance for 1930. In Sweden an enlarged capacity of the pulp industry reduces the present surplus of 0.4 million cu.m. to a deficit of 3.1 million cu.m. In Finland the annual over-cut will increase from 7 millions to 9.1 millions, new pulp mills accounting for about half the difference, and the Norwegian deficit of 1.2 millions, also a result of extra pulp tonnage.

It is expected that the dumping of Russian lumber on the European market will reduce the output from the sawmills of all three countries. The raw material thus available will probably be used for pulp in Sweden, helping to produce the annual deficit, but will be left standing in the woods in 
Norway and Finland, thus restricting the increases in annual deficits to new expansion of the present pulp industry.

The results of their forest surveys should enable the three Scandinavian countries to place their forest administrations on a firm basis, continuing their present policy of sustaining the annual production and maintaining the capital generally intact. Canada can learn a valuable and necessary lesson in forest management from these inventories of Sweden, Finland and Norway.

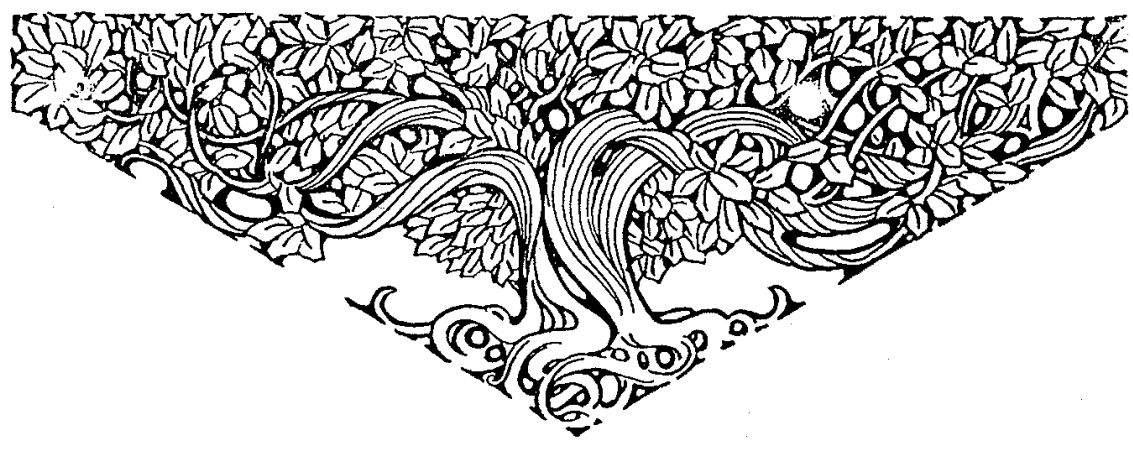


Table 2. Summary of AnNual Cut and InCREment

Total Total Increment Accessible Total

Volume Increment \% Increment annual cut Annual Deficit, 1925-27

Estimated Deficit, 1930

Country

Million Million

Million 1925-27 Million Percent

cu.m. million cu.m. of Total

Percent Million Percent Percent

cu.m. cu.m.

(b) cum. (b)

.m. of Total of Total

cullon Petal of Total

(a) (b)

Sweden

1417

47.7

Finland

1620

44.4

10.3

3.36
3.3

$41.5 \quad 41$.

$\begin{array}{ll}\text { (b) } & \text { (b) } \\ 41.1 & 0.4(c)\end{array}$

Cut Volume

(a)

(a)

Cut Volume

Norway

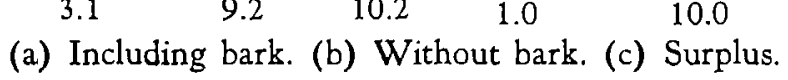

0.50

9.1

2.1

6.0
18.0

0.22 